\title{
An Efficient One Pot Protocol to the Annulation of Face "d" of Benzazepinone Ring with Pyrazole, Isoxazole, and Pyrimidine Nucleus through the Corresponding Oxoketene Dithioacetal Derivative
}

\author{
Aditi Anand, Navjeet Kaur, and Dharma Kishore \\ Department of Chemistry, Banasthali University, Banasthali, Raj 304022, India \\ Correspondence should be addressed to Navjeet Kaur; nvjithaans@gmail.com \\ Received 5 April 2014; Accepted 16 July 2014; Published 6 August 2014 \\ Academic Editor: Manuel Sergi
}

Copyright (C) 2014 Aditi Anand et al. This is an open access article distributed under the Creative Commons Attribution License, which permits unrestricted use, distribution, and reproduction in any medium, provided the original work is properly cited.

\begin{abstract}
A highly facile single step approach to the annulation of face "d" of benzazepinone nucleus with pyrazole, isoxazole, and pyrimidine ring has been described. The annulation proceeded smoothly on the reaction of oxoketene dithioacetal derivative 3 with (i) $\mathrm{NH}_{2}-$ $\mathrm{NH}_{2} \cdot \mathrm{H}_{2} \mathrm{O}$, (ii) $\mathrm{NH}_{2} \mathrm{OH} \cdot \mathrm{HCl}$, (iii) acetamidine hydrochloride, (iv) guanidine nitrate, (v) urea, and (vi) thiourea which yielded the pyrazolo, isoxazolo, and pyrimido annulated analogues of benzazepinone 4-9, respectively, in acceptable yields. The 4-ketene dithioacetal analogue of 7-fluorobenzo[b]azepine-2,5-dione (3) was in turn obtained from the reaction of 7-fluoro-3,4-dihydro- $1 \mathrm{H}$ benzo[b]azepine-2,5-dione (2) (with $\mathrm{CS}_{2}+\mathrm{CH}_{3} \mathrm{I}$ in presence of $t$-BuOK). 7-Fluoro-3,4-dihydro- $1 H$-benzo[b]azepine-2,5-dione (2) resulted from the acylation of $p$-fluoroaniline with succinyl chloride followed by cyclocondensation of the later with polyphosphoric acid (PPA)
\end{abstract}

\section{Introduction}

Koch et al. [1] have carried out a quantitative analysis of physiologically active natural products and showed that compound molecules with two or three rings were most often found in active natural products. The interest in the various facets of the chemistry and biology of small bicyclic and tricyclic (carbocyclic and heterocyclic) systems has expanded exponentially thereafter. Since then the development of small molecule libraries with potential biological activities has been a major focus of research in the area of chemical biology and medicinal chemistry. In view of this, the development of efficient methodologies to access small molecules of medicinal utility has been currently of special interest, with particular emphasis on the preparation of compound libraries from the privileged medicinal structures or from those structures akin to these.

Benzodiazepine framework in general has been recognized to belong to the family of "privileged medicinal structures," by virtue of their ability to provide ligands to a number of functionally and structurally discrete biological receptors. A derivative of benzazepine "the mirtazapine," being in close analogy to its activity, with 1,4-benzodiazepines, has emerged as an active antidepressant for the treatment of moderate to severe depression [2,3] (Figure 1). This discovery provided optimism towards the development of other novel agents from benzazepine class of compounds to find if there were others too, to show a higher level of medicinal efficacy. This search resulted in the discovery of 7-phenyl sulfonyl-tetrahydro-3-benzazepine derivative for its use as antipsychotic agent [4] and 6-chloro-2,3,4,5-tetrahydro-3methyl-1H-3-benzazepine to give relief in benign prostatic hypertrophy $[5,6]$.

Literature is replete with ample examples to show that the presence of an additional heterocyclic ring onto the seven membered ring of benzodiazepines exerts a profound influence on the biological activity in the resulting materials. Due to this, we considered it of interest to functionalize the benzazepine-2,5-dione system 2 with ketene dithioacetal 


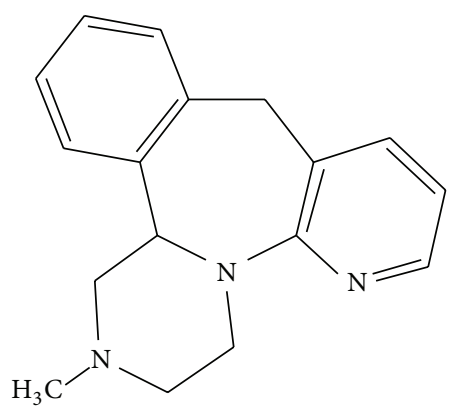

Mirtazapine
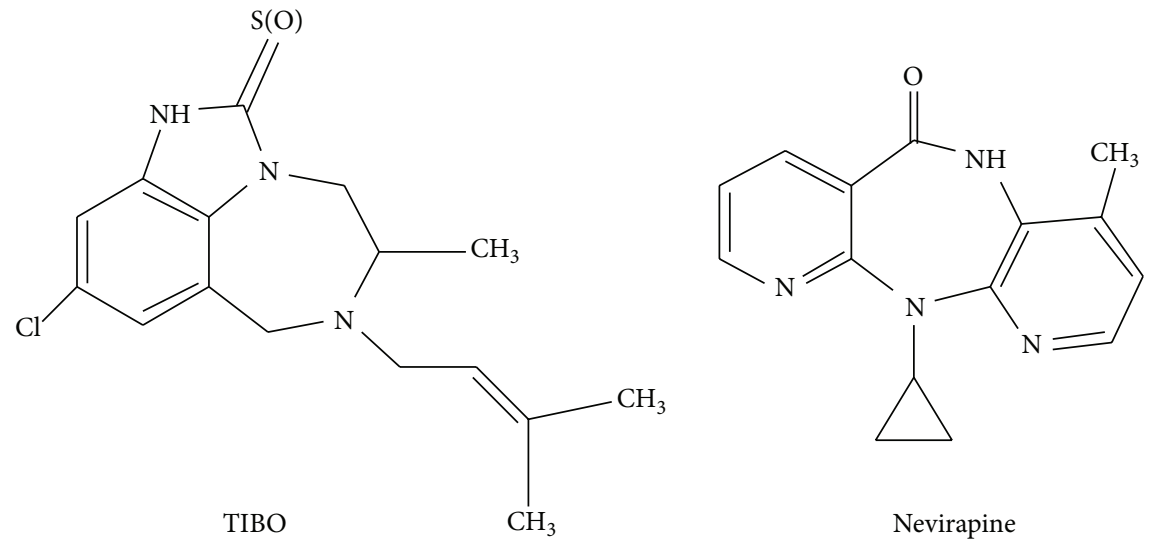

Nevirapine

Figure 1

function in consideration of their amenability to the corresponding pyrazolo, isoxazolo, and pyrimido annulated analogues 4-9, respectively, (Scheme 1) on the premise that their presence in tandem in the same molecular framework could inherit its positive impact onto the overall biological efficacy in the resulting molecules. Herein, in this communication, we report the preliminary results of our endeavour, focused in this direction.

\section{Materials and Method}

p-Fluoroaniline (1) and succinyl chloride were obtained from commercial sources and were used as obtained, from the sigma suppliers without further purification. Melting points were determined in open glass capillaries and are uncorrected. The purity of the compounds was checked by TLC on silica gel $(G)$ plates. IR spectra were recorded on CE (Schimatzu) FTIR-9050 S. ${ }^{1} \mathrm{H}-\mathrm{NMR}$ spectra and ${ }^{13} \mathrm{C}$ NMR spectra were recorded on Sea 400 (Bruker) using $\mathrm{CDCl}_{3}$ as solvent and TMS as an internal reference. Chemical shifts are expressed in $\delta$ ppm. Mass spectra were recorded on Bosch Tech. X.

\section{Experimental Section}

3.1. Synthesis of 7-Fluoro-3,4-dihydro-1H-benzo[b]azepine-2, 5-dione (2). p-Fluoroaniline (1) $(3.60 \mathrm{~mL}, 0.03 \mathrm{~mol})$ was mixed with succinyl chloride $(4.92 \mathrm{~g}, 0.03 \mathrm{~mol})$ in dry pyridine $(20.0 \mathrm{~mL})$ and the mixture was refluxed for $15 \mathrm{~min}$. Cold reaction mixture was poured slowly with stirring in 150-200 mL ice cold water. The separated solid was filtered, washed with cold water, and recrystallized using methanol and water. Polyphosphoric acid (25 g) was mixed to $3.21 \mathrm{~g}$ $(0.01 \mathrm{~mol})$ of separated solid and heated at $150-160^{\circ} \mathrm{C}$ for $4 \mathrm{~h}$ (the progress of the reaction was monitored by TLC). The reaction mixture was cooled to $20^{\circ} \mathrm{C}$ and a concentrated aqueous solution of $\mathrm{Na}_{2} \mathrm{CO}_{3}$ was added to make it alkaline. The product was extracted with ethyl acetate $(3 \times 10 \mathrm{~mL})$. The extract was dried over anhydrous sodium sulfate and concentrated in vacuum. The residue was purified by column chromatography on silica gel with $\mathrm{CHCl}_{3}$ as an eluent to give 2 (2.85 g, yield: 79\%): m.p.: $158-160^{\circ} \mathrm{C}$; IR $(\mathrm{KBr}) \mathrm{cm}^{-1}$ : 3240 (N-H str.), 2990 (C-H str.), 2900, 1400 ( $-\mathrm{CH}_{2}$ next to $\mathrm{C}=\mathrm{O}), 1680,1710$ (C=O str.), and 1535 (C=C str.); ${ }^{1} \mathrm{H}$ NMR $\left(400 \mathrm{MHz} \mathrm{CDCl}_{3}\right) \delta \mathrm{ppm}: 8.0(1 \mathrm{H}, \mathrm{s}, \mathrm{NH}), 7.26-7.78(3 \mathrm{H}$, $\mathrm{m}, \mathrm{Ar}-\mathrm{H})$, and $3.49\left(4 \mathrm{H}, \mathrm{m},\left(\mathrm{CH}_{2}\right)_{2}\right) ;{ }^{13} \mathrm{C} \mathrm{NMR}(400 \mathrm{MHz}$, $\left.\mathrm{CDCl}_{3}\right) \delta$ ppm: Ar-C [157.55 (CF), $120.24(\mathrm{CH}), 113.54(\mathrm{CH})$, $112.44(\mathrm{CH})], \mathrm{Ar}-\mathrm{C}[134.44(\mathrm{C}), 115.25(\mathrm{C})$, azepinone], 27.6, $34.4\left[\left(\mathrm{CH}_{2}\right)_{2}\right.$ azepinone)], 176.75 (C of amide), and 183.49 (C of carbonyl); MS: $m / z 193.17\left(\mathrm{M}^{+}\right)$; Anal. calcd./found for $\mathrm{C}_{10} \mathrm{H}_{8} \mathrm{FNO}_{2}$ : C 62.18/62.35, $\mathrm{H} 4.17 / 4.11$, and $\mathrm{N}$ 7.25/7.48.

3.2. Synthesis of 4-(Bis(methylthio)methylene)-7-fluoro-3,4dihydro-1H-benzo[b]azepine-2,5-dione (3). A mixture of 7fluoro-3,4-dihydro-1H-benzo[b]azepine-2,5-dione (2) (2.82 g, $0.01 \mathrm{~mol})$ and $\mathrm{CS}_{2}(1.6 \mathrm{~mL}, 0.01 \mathrm{~mol})$ was added to a wellstirred and cold suspension of $t$-BuOK $(2.23 \mathrm{~g}, 0.02 \mathrm{~mol})$ in dry benzene $(7.0 \mathrm{~mL})$ and DMF $(3.0 \mathrm{~mL})$ and the reaction mixture was allowed to stand for $4 \mathrm{~h}$. Methyl iodide $(3.3 \mathrm{~mL}$, $0.02 \mathrm{~mol}$ ) was gradually added with stirring and reaction mixture was maintained at low temperature by placing it in ice cold water bath. The reaction mixture was allowed to stand for $4 \mathrm{~h}$ at room temperature with occasional shaking followed by reflux on a water bath for $3 \mathrm{~h}$. The mixture was poured on crushed ice and the benzene layer was separated. The aqueous portion was extracted with benzene and the combined extracts were washed with water and dried over anhydrous sodium sulfate and the solvent was removed by distillation. The product thus obtained was purified by crystallization with ethanol to give 3 (1.7 g, yield: $60 \%)$ : m.p.: $155-157^{\circ} \mathrm{C}$; IR (KBr) cm ${ }^{-1}$ : 3240 (N-H str.), 3000 (C-H str.), 2900, $1400\left(-\mathrm{CH}_{2}\right.$ next to $\left.\mathrm{C}=\mathrm{O}\right), 1640,1685$ (C=O str.), 1620 ( $\mathrm{C}=\mathrm{C}$ str. of $\alpha, \beta$-unsaturated ketone), 1535 ( $\mathrm{C}=\mathrm{C}$ str.), and 680 (C-S str.); ${ }^{1} \mathrm{H}$ NMR (400 MHz, $\left.\mathrm{CDCl}_{3}\right) \delta \mathrm{ppm}: 8.0(1 \mathrm{H}$, s, NH), 7.45-7.98 (3H, m, Ar-H), $3.53\left(2 \mathrm{H}, \mathrm{s}, \mathrm{CH}_{2}\right)$, and 2.80 $\left(6 \mathrm{H}, \mathrm{s},\left(\mathrm{CH}_{3}\right)_{2}\right.$ of $\left.(\mathrm{SMe})_{2}\right) ;{ }^{13} \mathrm{C} \mathrm{NMR}\left(400 \mathrm{MHz}, \mathrm{CDCl}_{3}\right) \delta$ ppm: Ar-C [164.5 (CF), $121.5(\mathrm{CH}), 113.1(\mathrm{CH}), 112.6(\mathrm{CH})]$, Ar-C [136.8 (C), 136.0 (C), 108.7 (C), azepinone], 28.60 $\left(\mathrm{CH}_{2}\right.$ azepinone), 168.7 (C of amide), 187.0 (C of carbonyl), 155.3 [-C-(SMe $)_{2}$ ], and 18.0 [2C of $\left(\mathrm{CH}_{3}\right)_{2}$ ]; MS: $m / z 297.37$ $\left(\mathrm{M}^{+}\right)$; Anal. calcd./found for $\mathrm{C}_{13} \mathrm{H}_{12} \mathrm{FNO}_{2} \mathrm{~S}_{2}$ : C 52.51/52.32, $\mathrm{H}$ 4.07/4.01, N 14.71/14.48, and S 21.57/21.38. 


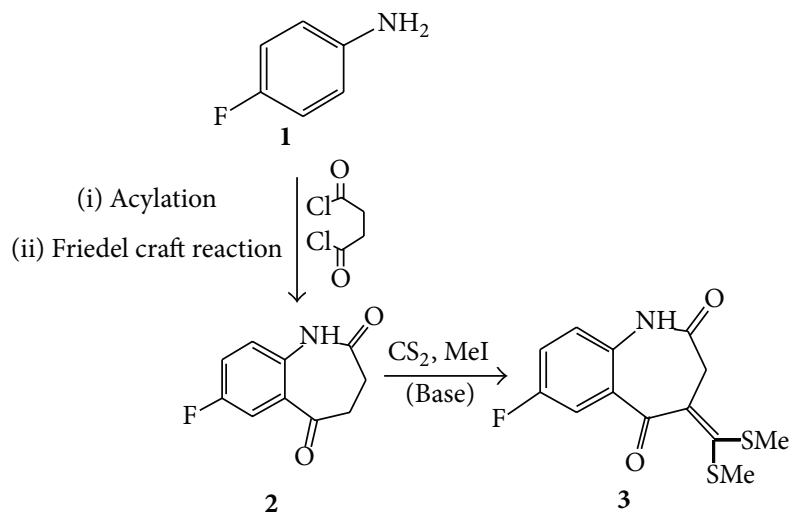

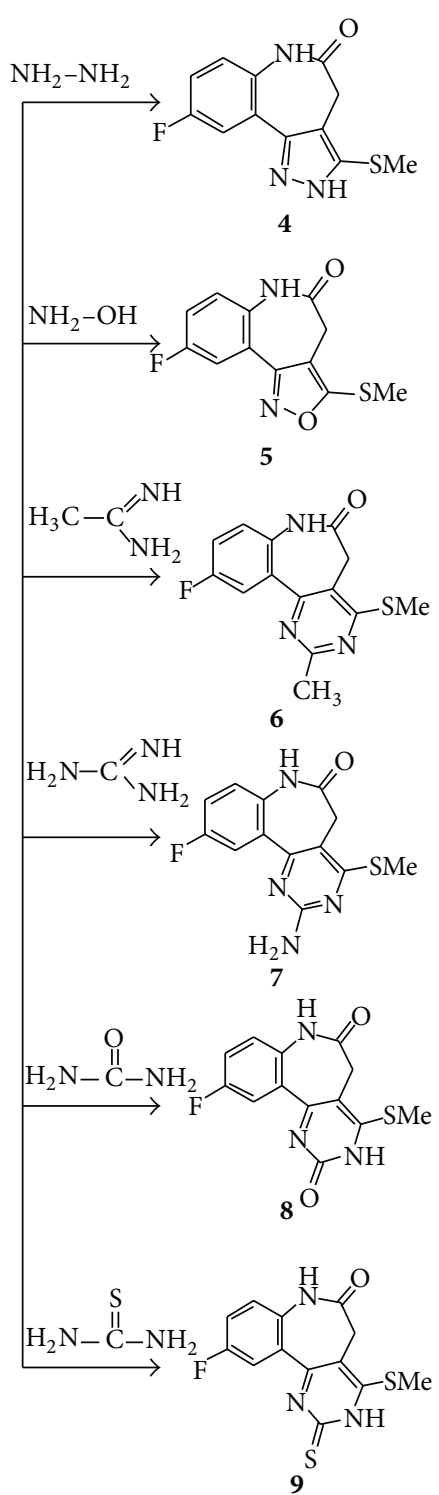

SCHEME 1

3.3. Synthesis of 9-Fluoro-3-(methylthio)-4,6-dihydrobenzo[b] pyrazolo[3,4-d]azepin-5(2H)-one (4). Hydrazine hydrate (1 $\mathrm{mL}, 0.02 \mathrm{~mol}$ ) and 4-(bis(methylthio)methylene)-7-fluoro3,4-dihydro- $1 H$-benzo[b] azepine-2,5-dione (3) (0.658g, $0.002 \mathrm{~mol})$ were taken in ethanol $(10.0 \mathrm{~mL})$ and refluxed for $3 \mathrm{~h}$. The solvent was removed and residue was dissolved in $5 \mathrm{~mL}$ of chloroform. On removal of the solvent, 4 was obtained (0.38 g, yield: 58\%): m.p.: $230-232^{\circ} \mathrm{C}$; IR ( $\left.\mathrm{KBr}\right)$ $\mathrm{cm}^{-1}$ : 3390 (N-H str.), 3210 (N-H str. of pyrazole ring), 3090 (C-H str.), 2990, $1400\left(-\mathrm{CH}_{2}\right.$ next to $\left.\mathrm{C}=\mathrm{O}\right), 1600(\mathrm{C}=\mathrm{O}$ str.), 1590 (C=C str.), 1515 ( $\mathrm{C}=\mathrm{N}$ str.), and 690 (C-S str.); ${ }^{1} \mathrm{H}$ NMR (400 MHz, $\left.\mathrm{CDCl}_{3}\right) \delta \mathrm{ppm}: 12.82(\mathrm{IH}, \mathrm{s}, \mathrm{NH}$ of pyrazole ring), $8.03(1 \mathrm{H}, \mathrm{s}, \mathrm{NH}), 7.59-8.51(3 \mathrm{H}, \mathrm{m}, \mathrm{Ar}-\mathrm{H}), 3.72(2 \mathrm{H}$, s, $\left.\mathrm{CH}_{2}\right)$, and $2.70\left(3 \mathrm{H}, \mathrm{s}, \mathrm{CH}_{3}\right.$ of SMe group); ${ }^{13} \mathrm{C}-\mathrm{NMR}$ $\left(400 \mathrm{MHz}, \mathrm{CDCl}_{3}\right) \delta$ ppm: Ar-C [168.83 (CF), $121.01(\mathrm{CH})$, $114.51(\mathrm{CH}), 114.49$ (CH)], Ar-C [143.29 (C), 131.82 (C), 123.11 (C), 97.33 (C), azepinone), 172.62 (C of amide), $39.60\left(\mathrm{CH}_{2}\right.$, azepinone), 130.57 (pyrazole, -CSMe), and $17.62\left(\mathrm{C}\right.$ of $\mathrm{CH}_{3}$ ); MS: $m / z 263.301\left(\mathrm{M}^{+}\right)$; Anal. calcd./found for $\mathrm{C}_{12} \mathrm{H}_{10} \mathrm{FN}_{3} \mathrm{OS}$ : C 54.74/54.52, H 3.83/3.89, N 15.96/15.36, and S 12.18/12.36.

3.4. Synthesis of 9-Fluoro-3-(methylthio)-4H-benzo[b]isoxazolo[3,4-d]azepin-5(6H)-one (5). Hydroxylamine hydrochloride $(0.34 \mathrm{~g}, 0.005 \mathrm{~mol})$ was added to sodium methoxide $(0.27 \mathrm{~g}, 0.005 \mathrm{~mol})$ in absolute methanol $(15 \mathrm{~mL})$ and mixture was stirred for $10 \mathrm{~min}$. 4-(bis (methylthio)methylene)-7-Fluoro-3,4-dihydro-1H-benzo[b]azepine-2,5-dione (3) (1.54 g, $0.005 \mathrm{~mol}$ ) was added and the mixture was refluxed for $5 \mathrm{~h}$. Excess of methanol was removed under reduced pressure and the mixture was poured into ice cold water. The solid thus separated was filtered, washed with diethyl ether, and dried. Recrystallization with ethanol gave the analytically pure product 5 (1.08 g, yield: $70 \%$ ): m.p.: $233-235^{\circ} \mathrm{C}$; IR (KBr) $\mathrm{cm}^{-1}$ : 3300 (N-H str.), 3010 (C-H str.), 2990, 1400 
( $-\mathrm{CH}_{2}$ next to $\mathrm{C}=\mathrm{O}$ ), 1600 ( $\mathrm{C}=\mathrm{O}$ str.), 1580 ( $\mathrm{C}=\mathrm{C}$ str.), 1510 (C=N str.), 900 (C-O-N str.), and 695 (C-S str.); ${ }^{1} \mathrm{H}$ NMR $\left(400 \mathrm{MHz}, \mathrm{CDCl}_{3}\right) \delta \mathrm{ppm}: 8.11(1 \mathrm{H}, \mathrm{s}, \mathrm{NH}), 7.25-8.34(3 \mathrm{H}$, $\mathrm{m}, \mathrm{Ar}-\mathrm{H}), 3.59\left(2 \mathrm{H}, \mathrm{s}, \mathrm{CH}_{2}\right)$, and $2.82\left(3 \mathrm{H}, \mathrm{s}, \mathrm{CH}_{3}\right) ;{ }^{13} \mathrm{C}$ $\mathrm{NMR}\left(400 \mathrm{MHz}, \mathrm{CDCl}_{3}\right) \delta \mathrm{ppm}$ : Ar-C [163.69 (CF), 123.11 $(\mathrm{CH}), 114.60(\mathrm{CH}), 114.41(\mathrm{CH})], \operatorname{Ar}-\mathrm{C}[143.11(\mathrm{C}), 139.13$ (C), 130.62 (C), 104.65 (C), azepinone], 172.62 (C of amide), $39.22\left(\mathrm{CH}_{2}\right.$ azepinone), and 138.10 (isoxazole $\left.\mathrm{C},-\mathrm{CSMe}\right), 17.61$ (C of $\mathrm{CH}_{3}$ ); MS: $m / z 264.281\left(\mathrm{M}^{+}\right)$; Anal. calcd./found for $\mathrm{C}_{12} \mathrm{H}_{9} \mathrm{FN}_{2} \mathrm{O}_{2} \mathrm{~S}: \mathrm{C} 54.54 / 54.24, \mathrm{H} 3.43 / 3.50, \mathrm{~N} 10.60 / 10.36$, and $S$ 12.13/12.32.

3.5. Synthesis of 10-Fluoro-2methyl-4-(methylthio)-5Hbenzo[b]pyrimido[4,5-d]azepin-6(7H)-one (6). To 4-(bis (methylthio)methylene)-7-fluoro-3,4-dihydro- $1 H$-benzo[b] azepine-2,5-dione (3) (1.48 g, $0.005 \mathrm{~mol})$ in EtOH $(5.0 \mathrm{~mL})$ was added acetamidine hydrochloride $(0.54 \mathrm{~g}, 0.005 \mathrm{~mol})$ and triethylamine $(0.50 \mathrm{~mL}, 0.005 \mathrm{~mol})$. The solution was heated under reflux for $45 \mathrm{~h}$ and concentrated. The residue was extracted with ethyl acetate and washed with water. The organic layer was extracted with chloroform, dried over anhydrous magnesium sulfate, and evaporated. The residue was purified by column chromatography by eluting with hexane: ethyl acetate to give brown powder. The solid was recrystallized with ethanol to give $6(0.98 \mathrm{~g}$, yield: $66 \%)$ : m.p.: 229-231 ${ }^{\circ} \mathrm{C}$; IR (KBr) cm ${ }^{-1}: 3300$ (N-H str.), 3000 (C-H str.), $2990\left(\mathrm{CH}_{3}\right.$ str.), 2980, $1400\left(-\mathrm{CH}_{2}\right.$ next to $\left.\mathrm{C}=\mathrm{O}\right), 1600$ ( $\mathrm{C}=\mathrm{O}$ str.), 1570 ( $\mathrm{C}=\mathrm{C}$ str.), 1510 ( $\mathrm{C}=\mathrm{N}$ str.), and 680 (C-S str.); ${ }^{1} \mathrm{H}$ NMR $\left(400 \mathrm{MHz}, \mathrm{CDCl}_{3}\right) \delta$ ppm: $8.15(1 \mathrm{H}, \mathrm{s}, \mathrm{NH})$, 7.54-8.37 (3H, m, Ar-H), $3.97\left(2 \mathrm{H}, \mathrm{s}, \mathrm{CH}_{2}\right), 2.93(3 \mathrm{H}, \mathrm{s}$, $\mathrm{CH}_{3}$ of $\left.\mathrm{SMe}\right)$, and $2.71\left(3 \mathrm{H}, \mathrm{s}, \mathrm{CH}_{3}\right) ;{ }^{13} \mathrm{C} \mathrm{NMR}(400 \mathrm{MHz}$, $\left.\mathrm{CDCl}_{3}\right) \delta$ ppm: Ar-C [163.75 (CF), $123.11(\mathrm{CH}), 114.62$ $(\mathrm{CH}), 114.44(\mathrm{CH})]$, Ar-C [157.72 (C), $143.22(\mathrm{C}), 130.62(\mathrm{C})$, $115.02(\mathrm{C})$, azepinone], $39.22\left(\mathrm{CH}_{2}\right.$ azepinone), 170.50 ( $\mathrm{C}$ of amide), 170.41 (pyrimidine $\mathrm{C},-\mathrm{CCH}_{3}$ ), 172.56 (pyrimidine C, $-\mathrm{CSMe}$ ), 24.27 ( $\mathrm{C}$ of $\mathrm{CH}_{3}$, pyrimidine), and 17.01 ( $\mathrm{C}$ of $\left.\mathrm{CH}_{3},-\mathrm{SMe}\right)$; MS: $m / z 289.331\left(\mathrm{M}^{+}\right)$; Anal. calcd./found for $\mathrm{C}_{14} \mathrm{H}_{12} \mathrm{FN}_{3}$ OS: C 58.12/58.31, H 4.18/4.12, N 14.52/14.24, and S 11.08/11.26.

3.6. Synthesis of 2-Amino-10-fluoro-4-(methylthio)-5Hbenzo[b]pyrimido[4,5-d]azepin-6-(7H)one (7). To 4-(bis (methylthio)methylene)-7-fluoro-3,4-dihydro- $1 \mathrm{H}$-benzo[b] azepine-2,5-dione (3) $(1.48 \mathrm{~g}, 0.005 \mathrm{~mol})$ in $\mathrm{EtOH}(5.0 \mathrm{~mL})$ were added guanidine nitrate $(0.61 \mathrm{~g}, 0.005 \mathrm{~mol})$ and triethylamine $(0.50 \mathrm{~mL}, 0.005 \mathrm{~mol})$. The solution was heated under reflux for $45 \mathrm{~h}$ and concentrated. The residue was extracted with ethyl acetate and washed with water. The organic layer was extracted with chloroform, dried over anhydrous magnesium sulfate, and evaporated. The residue was purified by column chromatography by eluting with hexane: ethyl acetate to give brown powder. The solid was recrystallized with ethanol to give 7 (0.96 g, yield: $65 \%)$ : m.p. $260-262^{\circ} \mathrm{C}$; IR (KBr) cm ${ }^{-1}: 3380$ (N-H str.), $3270\left(\mathrm{NH}_{2}\right.$ str.), 3000 (C-H str.), 2975, 1400 ( $-\mathrm{CH}_{2}$ next to $\left.\mathrm{C}=\mathrm{O}\right), 1650$ ( $\mathrm{C}=\mathrm{O}$ str.), 1540 ( $\mathrm{C}=\mathrm{C}$ str.), 1510 ( $\mathrm{C}=\mathrm{N}$ str.), and 680 (C-S str.); ${ }^{1} \mathrm{H}$ NMR $\left(400 \mathrm{MHz}, \mathrm{CDCl}_{3}\right) \delta$ ppm: $8.13(1 \mathrm{H}, \mathrm{s}, \mathrm{NH})$, 7.58-8.83 (3H, m, Ar-H), $6.59\left(2 \mathrm{H}, \mathrm{s}, \mathrm{NH}_{2}\right), 3.97(2 \mathrm{H}, \mathrm{s}$,
$\left.\mathrm{CH}_{2}\right)$, and $2.82\left(3 \mathrm{H}, \mathrm{s}, \mathrm{CH}_{3}\right) ;{ }^{13} \mathrm{C} \mathrm{NMR}\left(400 \mathrm{MHz}, \mathrm{CDCl}_{3}\right)$ $\delta$ ppm: Ar-C [163.73 (CF), $123.14(\mathrm{CH}), 114.62(\mathrm{CH}), 114.44$ $(\mathrm{CH})$, Ar-C [158.62 (C), 143.33 (C), 130.65 (C), 115.09 (C), azepinone], 39.24 ( $\mathrm{CH}_{2}$ azepinone), 170.50 ( $\mathrm{C}$ of amide), 166.44 (pyrimidine $\mathrm{C},-\mathrm{CNH}_{2}$ ), 172.54 (pyrimidine $\mathrm{C}$, -CSMe), and 17.03 ( $\mathrm{C}$ of $\left.\mathrm{CH}_{3}\right)$; MS: $m / z 290.32\left(\mathrm{M}^{+}\right)$; Anal. calcd./found for $\mathrm{C}_{13} \mathrm{H}_{11} \mathrm{FN}_{4}$ OS: C 53.78/53.59, $\mathrm{H}$ 3.82/3.76, $\mathrm{N}$ 19.30/19.11, and S 11.04/11.25.

3.7. Synthesis of 10-Fluoro-4-(methylthio)-5,7-dihydro-2Hbenzo[b]pyrimido[4,5-d]azepin-2,6- $(3 \mathrm{H})$-dione (8). To a mixture of urea $(0.12 \mathrm{~g}, 0.002 \mathrm{~mol})$ and sodium ethoxide $(0.14 \mathrm{~g}, 0.002 \mathrm{~mol})$ in ethanol $(10.0 \mathrm{~mL}), 4$-(bis(methylthio)methylene)-7-fluoro-3,4-dihydro- $1 H$-benzo [b]azepine-2, 5 -dione (3) $(0.658 \mathrm{~g}, 0.002 \mathrm{~mol})$ was added. The reaction mixture was refluxed for $12 \mathrm{~h}$. The solvent was removed by distillation and the residue was treated with glacial acetic acid $(10.0 \mathrm{~mL})$ just enough to dissolve sodium salt of pyrimidine and the mixture was refluxed for $15 \mathrm{~min}$. It was poured on crushed ice and the precipitate obtained was purified by recrystallization from ethanol to give 8 (0.41 g, yield: $62 \%)$ : m.p. $225-228^{\circ} \mathrm{C}$; IR (KBr) cm ${ }^{-1}$ : 3380 (N-H str.), 3000 (C-H str.), 2980, 1400 ( $-\mathrm{CH}_{2}$ next to $\left.\mathrm{C}=\mathrm{O}\right), 1670,1710$ ( $\mathrm{C}=\mathrm{O}$ str.), 1570 (C=C str.), 1500 (C=N str.), and 685 (C-S str.); ${ }^{1} \mathrm{H}$ NMR $\left(400 \mathrm{MHz} \mathrm{CDCl}_{3}\right) \delta \mathrm{ppm}: 8.04(1 \mathrm{H}, \mathrm{s}, \mathrm{NH}), 7.34-8.45(3 \mathrm{H}$, $\mathrm{m}, \mathrm{Ar}-\mathrm{H}), 3.72\left(2 \mathrm{H}, \mathrm{s}, \mathrm{CH}_{2}\right), 2.90\left(3 \mathrm{H}, \mathrm{s}, \mathrm{CH}_{3}\right)$, and $2.0(1 \mathrm{H}$, $\mathrm{s}, \mathrm{NH}$ of pyrimidine ring); ${ }^{13} \mathrm{C} \mathrm{NMR}\left(400 \mathrm{MHz}, \mathrm{CDCl}_{3}\right) \delta$ ppm: Ar-C [163.79 (CF), $122.08(\mathrm{CH}), 114.52(\mathrm{CH}), 114.42$ (CH)], Ar-C [155.82 (C), 141.42 (C), 144.24 (C), 115.02 (C), azepinone], $39.21\left(\mathrm{CH}_{2}\right.$, azepinone), 171.47 ( $\mathrm{C}$ of amide), 170.42 (pyrimidine $\mathrm{C},-\mathrm{CSMe}), 166.4$ (C of carbonyl), and $17.06\left(\mathrm{C}\right.$ of $\left.\mathrm{CH}_{3}\right)$; MS: $m / z 291.30\left(\mathrm{M}^{+}\right)$; Anal. calcd./found for $\mathrm{C}_{13} \mathrm{H}_{10} \mathrm{FN}_{3} \mathrm{O}_{2} \mathrm{~S}$ : C 53.60/53.38, $\mathrm{H}$ 3.46/3.41, N 14.42/ 14.13, and $S$ 11.01/11.28.

3.8. Synthesis of 10-Fluoro-4-(methylthio)-2-thioxo-5,7dihydro-2H-benzo[b]pyrimido[4,5-d]azepin-2,6-(3H)-one

(9). To a mixture of thiourea $(0.12 \mathrm{~g}, 0.002 \mathrm{~mol})$ and sodium ethoxide $(0.14 \mathrm{~g}, 0.002 \mathrm{~mol})$ in ethanol $(10.0 \mathrm{~mL}), 4$ -(bis(methylthio)methylene)-7-fluoro-3,4-dihydro- $1 \mathrm{H}$ benzo[b]azepine-2,5-dione (3) (0.658 g, $0.002 \mathrm{~mol})$ was added and the reaction mixture was refluxed for $12 \mathrm{~h}$. The solvent was removed by distillation and the residue was treated with glacial acetic acid $(10.0 \mathrm{~mL})$ just enough to dissolve sodium salt of pyrimidine and the mixture was refluxed for $15 \mathrm{~min}$. It was poured on crushed ice and the precipitate obtained was purified by recrystallization from ethanol to give 9 ( 0.44 g, yield: $67 \%)$ : m.p.: $275-277^{\circ} \mathrm{C}$; IR (KBr) cm ${ }^{-1}$ : 3370 (N-H str.), 2990 (C-H str.), 2980, 1400 ( $-\mathrm{CH}_{2}$ next to $\mathrm{C}=\mathrm{O}$ ), 1680 ( $\mathrm{C}=\mathrm{O}$ str.), 1570 ( $\mathrm{C}=\mathrm{C}$ str.), 1510 (C=N str.), 780 (C=S str.), and 690 (C-S str.); ${ }^{1} \mathrm{H}$ NMR $\left(400 \mathrm{MHz}, \mathrm{CDCl}_{3}\right) \delta$ ppm: $8.04(1 \mathrm{H}, \mathrm{s}, \mathrm{NH}), 7.34-8.44$ $(3 \mathrm{H}, \mathrm{m}, \mathrm{Ar}-\mathrm{H}), 3.90\left(2 \mathrm{H}, \mathrm{s}, \mathrm{CH}_{2}\right), 2.92\left(3 \mathrm{H}, \mathrm{s}, \mathrm{CH}_{3}\right)$, and $2.0\left(1 \mathrm{H}, \mathrm{s}, \mathrm{NH}\right.$ of pyrimidine ring); ${ }^{13} \mathrm{C} \mathrm{NMR}(400 \mathrm{MHz}$, $\left.\mathrm{CDCl}_{3}\right) \delta$ ppm: Ar-C [163.58 (CF), $122.08(\mathrm{CH}), 114.52$ $(\mathrm{CH}), 114.42(\mathrm{CH})]$, Ar-C [156.62 (C), $143.22(\mathrm{C}), 136.63(\mathrm{C})$, $115.02(\mathrm{C})$, azepinone], $39.20\left(\mathrm{CH}_{2}\right.$ azepinone), 171.23 (C of amide), 170.42 (pyrimidine $\mathrm{C},-\mathrm{CSMe}), 17.07\left(\mathrm{C}\right.$ of $\left.\mathrm{CH}_{3}\right)$, 
and 180.4 (pyrimidine $\mathrm{C},-\mathrm{C}=\mathrm{S}$ ); $\mathrm{MS}: m / z 307.37\left(\mathrm{M}^{+}\right)$; Anal. calcd./found for $\mathrm{C}_{13} \mathrm{H}_{10} \mathrm{FN}_{3} \mathrm{OS}_{2}$ : C 50.80/50.64, $\mathrm{H}$ 3.28/3.21, $\mathrm{N} 13.67 / 13.38$, and $\mathrm{S} 20.86 / 20.44$.

\section{Results and Discussion}

The synthetic importance of oxoketene dithioacetals specially the dimethyl thioacetal in the construction of a variety of novel fused heterocyclic systems encouraged us to explore its potential in the annulation of face " $\mathrm{d}$ " of 7-fluorobenzazepine-2,5-dione (2) with such pharmacophoric scaffolds as pyrazole, isoxazole, and pyrimidine which have been accredited in the literature with a proven record of their bioactive profiles. In consideration of the easy accessibility of the corresponding ketene dimethyl acetals from the base catalyzed reaction of $\mathrm{CS}_{2}$ and $\mathrm{CH}_{3} \mathrm{I}$ with compounds containing an active methylene group, we applied this strategy on 2 to append this functionality onto its 4 -position to form 3 . The versatility of 3 in allowing a facile annulation of its face " $d$ " with the above bioactive pharmacophores was exploited in its reaction with (i) hydrazine hydrate [7], (ii) hydroxylamine hydrochloride [8-10], (iii) acetamidine hydrochloride [11], (iv) guanidine nitrate [11], (v) urea [12], and (vi) thiourea [12] to generate 4-9, respectively, in acceptable yields.

The structures of the compounds 2-9 were established on the basis of their microanalysis, IR, ${ }^{1} \mathrm{H}$ NMR,${ }^{13} \mathrm{C} N M R$, and MS data which corroborated strongly to the structures assigned to these molecules. The formation of compound 2 from 1 was ascertained by the appearance of two carbonyls in the IR spectrum of 2 (at 1680 and $1710 \mathrm{~cm}^{-1}$ ). The presence of a multiplet (due to two overlapping triplets of two $\mathrm{CH}_{2}$ 's) at $\delta 3.49$ in its NMR spectrum corroborated strongly its formation from 1 . The appearance of a carbonyl group peak at $1640 \mathrm{~cm}^{-1}$ for the $\alpha, \beta$-unsaturated ketone in the IR spectrum of 3 and a singlet of $2 \mathrm{H}$ for the $\mathrm{CH}_{2}$ group at $\delta 3.53$ in its NMR spectrum indicated clearly its formation from 2. The most diagnostic evidence which substantiated their formation was the disappearance of one of the carbonyl group peaks of 3 in the IR spectrum of 4-9 which confirmed its involvement in cyclocondensation reactions. The ${ }^{1} \mathrm{H}$ NMR spectrum $\left(400 \mathrm{MHz}\right.$, in $\left.\mathrm{CDCl}_{3}\right)$ of $3,5,6$, and 7 showed the presence of an NH peak at $\delta, 8.0,8.11,8.15$, and 8.13, respectively, (for the azepinone $\mathrm{NH}$ ) whereas compound 4 exhibited two NH peaks at $\delta, 12.82$ (pyrazole $\mathrm{NH}$ ) and $\delta, 8.03$ (for azepinone $\mathrm{NH}$ ). Apart from this, compounds $\mathbf{8}$ and $\mathbf{9}$ also exhibited two $\mathrm{NH}$ peaks at $\delta, 8.04$ (for azepinone $\mathrm{NH}$ ) and $\delta$, 2.0 (pyrimidine $\mathrm{NH}$ ), all of which exchanged with $\mathrm{D}_{2} \mathrm{O}$.

\section{Conclusion}

In summary, the unprecedented potential of oxoketene dithioacetals in synthesis was exploited to provide an easy access to face "d" pyrazolo, isoxazolo, and pyrimido annulated analogues of benzazepinone 4-9, respectively, from 4-ketene dimethyl thioacetal substituted derivative of 7-fluorobenzo(b)-azepine-2,5-dione (3). The process is characterized by mild reaction condition and easy work-up procedure.

\section{Conflict of Interests}

The authors declare that there is no conflict of interests regarding the publication of this paper.

\section{Acknowledgments}

Authors are thankful to Punjab University, Chandigarh, for providing the spectral data of the compounds. Authors are also thankful to Department of Science and Technology (DST), New Delhi, for financial support provided to Banasthali Center for Education and Research in Basic Sciences under their CURIE (Consolidation of University Research for Innovation and Excellence in Women Universities) programme.

\section{References}

[1] M. A. Koch, A. Schuffenhauer, M. Scheck et al., "Charting biologically relevant chemical space: a structural classification of natural products (SCONP)," Proceedings of the National Academy of Sciences of the United States of America, vol. 102, no. 48, pp. 17272-17277, 2005.

[2] D. D. C. Wan, D. Kundhur, and R. W. J. Lam, "Mirtazapine for treatment-resistant depression: a preliminary report," Journal of Psychiatry and Neuroscience, vol. 28, no. 1, pp. 55-59, 2003.

[3] O. L. Munk and F. Smith, "PET kinetics of radiolabeled antidepressant, $\left[N\right.$-methyl- $\left.{ }^{11} \mathrm{C}\right]$ mirtazapine, in the human brain," EJNMMI Research, vol. 1, article 36, 2011.

[4] H. R. Howard, "7-Phenylsulfonyl-tetrahydro-3-benzazepine derivatives as antipsychotic agents," Informa Healthcare, vol. 15, pp. 1811-1815, 2005.

[5] J. P. Hieble, "Method of treating benign prostatic hypertrophy," Patent 4755507, 2010.

[6] N. Dhingra and D. Bhagwat, "Benign prostatic hyperplasia: an overview of existing treatment," Indian Journal of Pharmacology, vol. 43, no. 1, pp. 6-12, 2011.

[7] W. W. Wardakhan and N. A. Louca, "Synthesis of novel pyrazole, coumarin and pyridazine derivatives evaluated as potential antimicrobial and antifungal agents," Journal of the Chilean Chemical Society, vol. 52, no. 2, pp. 1145-1149, 2007.

[8] P. K. Mahata, U. K. S. Kumar, V. Sriram, H. Ila, and H. Junjappa, "1-Bis(methoxy)-4-bis(methylthio)-3-buten-2-one: useful three carbon synthon for synthesis of five and six membered heterocycles with masked (or unmasked) aldehyde functionality," Tetrahedron, vol. 59, no. 15, pp. 2631-2639, 2003.

[9] J. Kaffy, R. Pontikis, D. Carrez, A. Croisy, C. Monneret, and J. Florent, "Isoxazole-type derivatives related to combretastatin A4, synthesis and biological evaluation," Bioorganic and Medicinal Chemistry, vol. 14, no. 12, pp. 4067-4077, 2006.

[10] M. V. D. Tresa and P. Melo, "Recent advances on the synthesis and reactivity of isoxazoles," Current Organic Chemistry, vol. 9, no. 10, pp. 925-958, 2005.

[11] M. A. Ebraheem, K. M. L. Rai, N. U. Kudva.n, and A. S. Bahjat, "Synthesis of new polysubstituted (pyrazoles, pyrimidines and quinolines) five and six-membered heterocycles: reaction of $\alpha, \alpha$-dioxoketene dithioacetals with nucleophiles," Tetrahedron Letters, vol. 51, no. 27, pp. 3486-3492, 2010.

[12] M. M. Abdelhalim, M. M.T. El-Saidi, S. T. Rabie, and G. A. Elmegeed, "Synthesis of novel steroidal heterocyclic derivatives as antibacterial agents," Steroids, vol. 72, no. 5, pp. 459-465, 2007. 

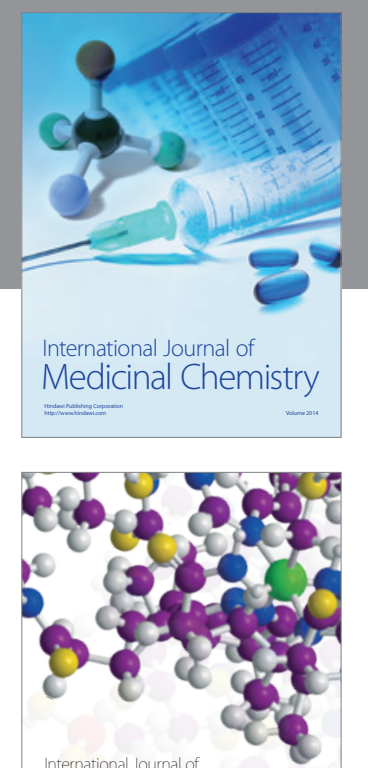

\section{Carbohydrate} Chemistry

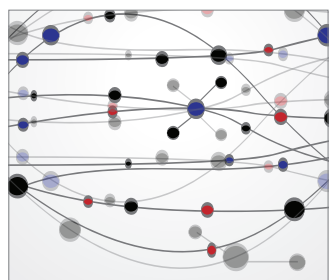

The Scientific World Journal
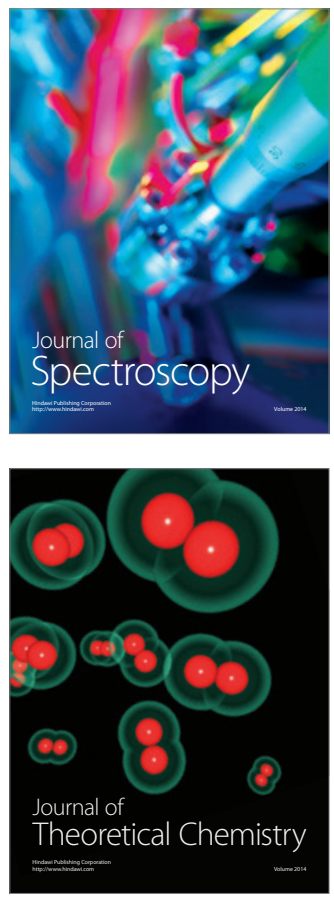
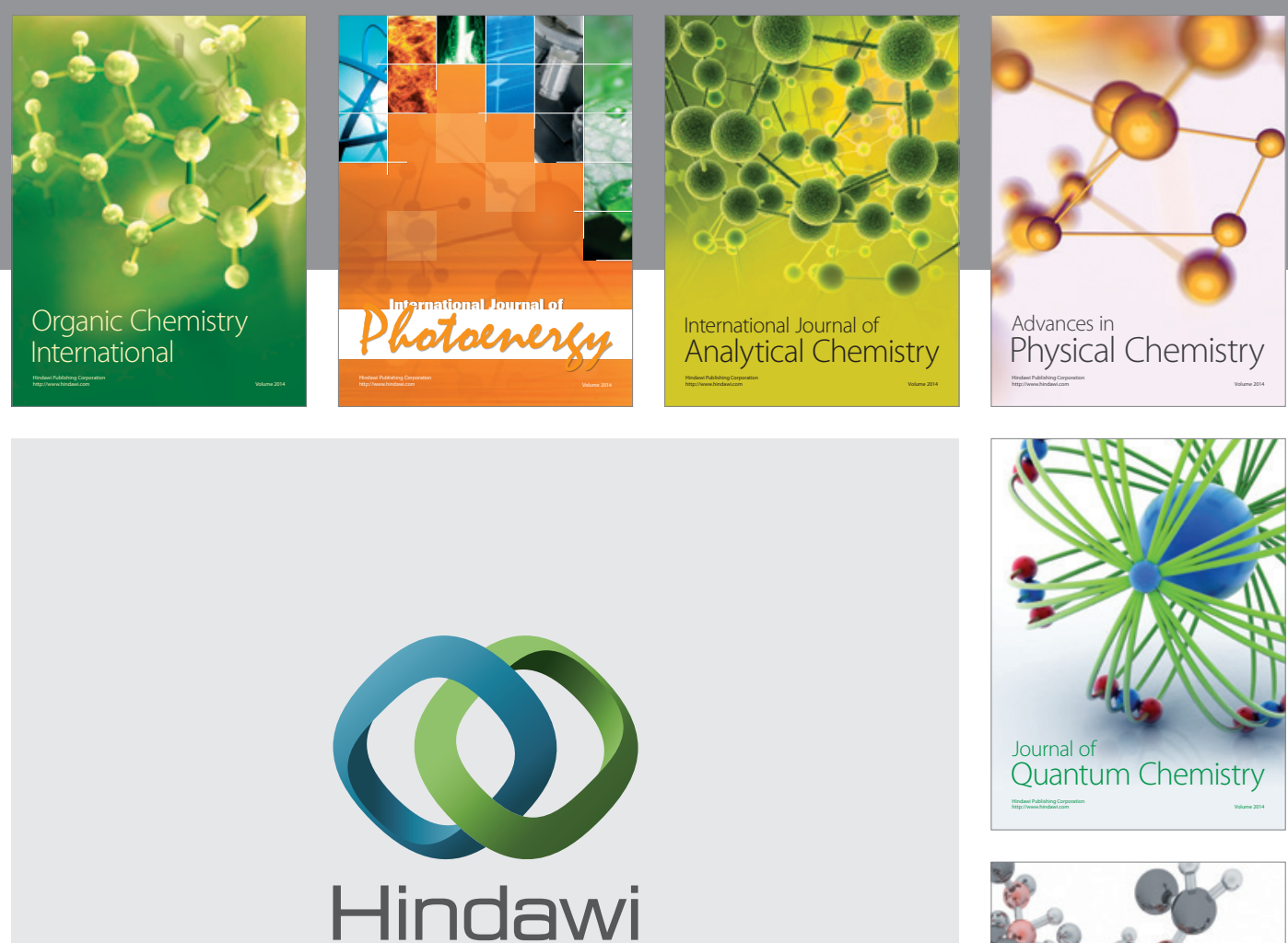

Submit your manuscripts at

http://www.hindawi.com

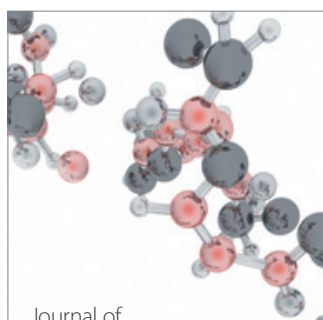

Analytical Methods

in Chemistry

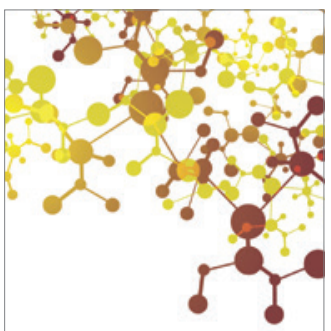

Journal of

Applied Chemistry

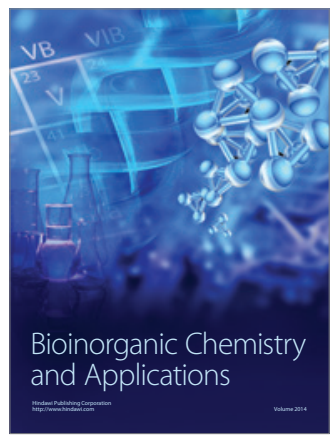

Inorganic Chemistry
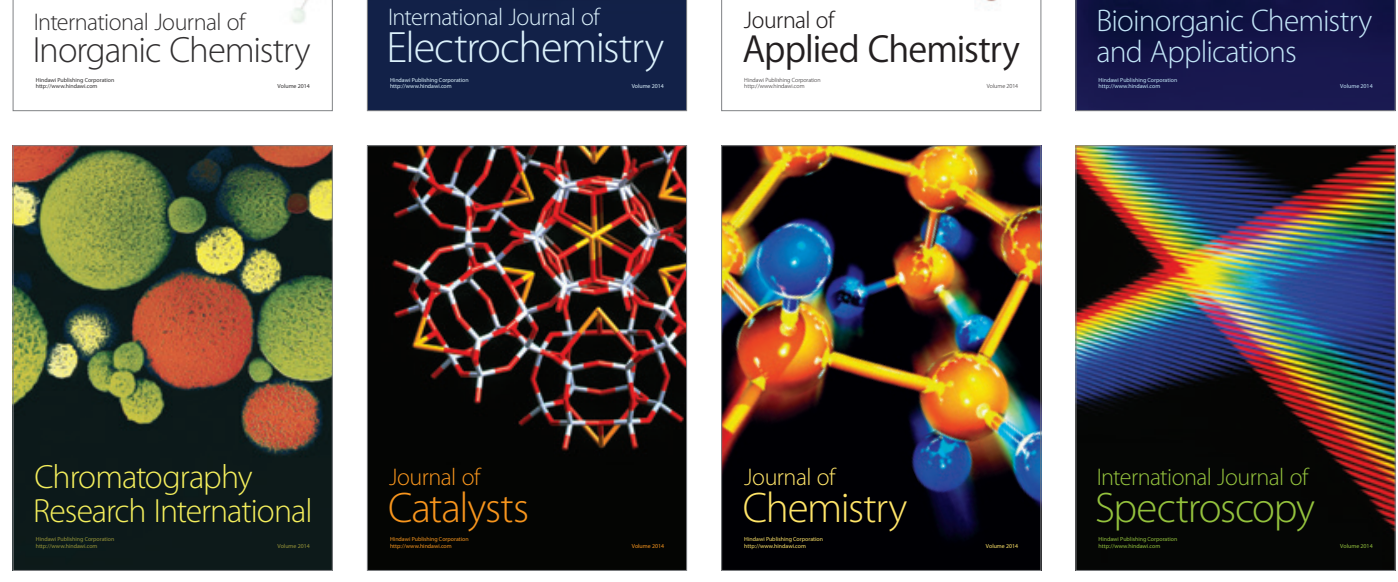